\title{
A phenomenological study to explore the mother's experiences on pregnancy, childbirth and postnatal period among high risk mothers at RGGW\&CH, Puducherry
}

\author{
Mrs. Deveena Sona Mehta \\ Pondicherry
}

\begin{abstract}
The experience of antenatal, intrapartum and postnatal care is an important life experience; these memories accompany women throughout life. Pregnancy and the birth of a child are significant and challenging events in a woman's life, associated with considerable physical and psychological change. In developing countries the focus has understandably been on women's physical health and there has been comparatively little research exploring women's experiences of pregnancy and childbirth pregnancy and delivery is a journey to unknown world.
\end{abstract} Purposive sampling technique was employed to select sample and it consisted of 20 postnatal mothers who met the inclusion criteria. Modified Sawyer et al interview questionnaire which contained open-ended questionnaires and demographic proforma was used to collect data. The researcher interviewed the participants and it was tape-recorded. Findings showed that with regard to the high-risk condition, the majority (55.0\%) subjects had $\mathrm{PIH},(20.0 \%)$ subjects had hypothyroidism, (15.0\%) subjects had GDM and $(10.0 \%)$ subjects had oligohydramnios, anemia, bronchial asthma, twin pregnancy, edema and eclampsia each. Minimum (5.0\%) of the subjects were obese. The result highlighted that majority $25 \%$ of the participants took extra precautions, $20 \%$ of the participants had increased fear and were worried about their outcome and $15 \%$ were struggling to believe that they had the disease. Majority of the participants $25 \%$ did not want another child, 20\% opted for surgery and $10 \%$ thought about their mother, lost hope. Majority of the participants 30\% wanted support from their mother and 20\% wanted support from their husband. There was no association between the experiences of high-risk mothers and specific demographic data. Experiences of high-risk mothers revealed that life after diagnosis, expectations of birth outcome and increased responsibility.

\section{INTRODUCTION}

"The hand of a bride becomes the hand of a mother. Ever so gently, she cares for her precious child. Bathing, dressing, feeding, comforting - there is no hand like mothers. Nor does its tender care diminish through the years."

—Thomas S. Monson

Being a Motherhood is a choice you make every day, to put someone else's happiness -and well-being ahead of your own, to teach the hard lessons, to do the right thing even when you're not sure what the right thing is and to forgive yourself, over and over again, for doing everything wrong." (Simon \& Ump; Schuster, 2011).

The experience of antenatal, intrapartum and postnatal care is an important life experience; these memories accompany women throughout life. Pregnancy and the birth of a child are significant and challenging events in a woman's life, associated with considerable physical and psychological change. (Jayita, Murali, 2009) 


\section{Statement of the problem}

"A phenomenological study to explore the mother's experiences on pregnancy, childbirth and postnatal period among high risk mothers at RGGW\&CH, Puducherry."

\section{Objectives}

1. To explore the high-risk mothers' experiences on pregnancy.

2. To explore the high-risk mothers' experiences on childbirth.

3. To explore high-risk mothers' experiences on postnatal period.

4. To associate the experiences of high-risk mothers with specific demographic variables.

\section{Delimitation}

The study is delimited to

1. The data collection period is only for 4 weeks.

2. The data is collected at $\mathrm{RGGW} \& \mathrm{CH}$, Puducherry.

3. The sample size is 20 .

\section{REVIEW OF LITERATURE}

Li Ge et al (2015) conducted a study "Beliefs about health and illness and health-related behaviour among urban women with gestational diabetes mellitus in the southeast of China." It explored that they feared the negative influence of gestational diabetes, but some of them believed in "letting nature take its course" and "living in the present." Their care-seeking behaviour varied between the professional, popular, and folk sectors. They sought a balance between following professionals' advice and avoiding practical difficulties.

Mary Carolan (2013) conducted a qualitative study“ To explore women's experiences of self-managing their gestational diabetes."Findings showed that incremental adjustment occurred over 4 discrete themes, including: (1) the shock of diagnosis; (2) coming to terms with GDM; (3) working it out/learning new strategies; (4) looking to the future. Each adjustment phase was underpinned by the fifth theme (5) having a supportive environment.
Throughout, participants reported that thinking about the baby was a powerful motivator for adherence to gestational diabetes management regimens.

\section{RESEARCH METHODOLOGY}

$>$ Research approach: Qualitative approach.

$>$ Research Design: Phenomenological design.

$>$ Research Setting: Postnatal ward at Rajiv Gandhi Government Women and Children Hospital -Puducherry

$>$ Population: high-risk postnatal mothers who were admitted at Puducherry.

$>$ Sample \& Sample Size: 20 subjects who are high-risk postnatal mothers and those who met the inclusion criteria.

> Sampling Technique: Purposive sampling technique.

\section{Sample Selection Criteria}

\section{Inclusion Criteria:}

Postnatal mothers who are:

1. Primi mothers with high-risk pregnancy.

2. Present during the period of data collection.

3. Understand the local language.

\section{Exclusion criteria:}

1. Postnatal mothers who are mentally ill.

2. Mothers not willing to participate.

\section{Development and description of Data Collection Tool}

The tool used for this study consists of two sections, section - A:Demographic data (Kuppusamy Socioeconomic scale) and Obstetrical history andsection - B:Modified Sawyer et al interview questionnaire.

Section A: It includes the baseline data. The background information about the client was included in the section that has about 7 items: Mother's name, age, dwelling area, marital status, socio-economic class, obstetrical complication and hours in labour. 
Section B: It includes the semi-structured questionnaires for the interview. The researcher used the modified Sawyer et al questionnaire. It consists of 12 open questions that covered the areas of pregnancy, childbirth and postnatal experiences.

\section{Ethical Consideration}

The permission was obtained from the medical superintendent and Ethical Committee of Rajiv Gandhi Government Women and Children Hospital, Puducherry. The selection of the mothers was based on inclusion criteria. Moreover, informed consent was obtained from each mother in both oral and written form. The mothers had the freedom to withdraw from the study at any time.

\section{Data collection method}

Researcher introduced herself and explained the study to the subjects. Informed consent was obtained from the mothers recruited for the study. Mothers were informed about the study. Participant's sociodemographic data was collected with the use of a questionnaire. Researcher conducted face-to-face interviews with all 20 participants in a conducive environment. Interviews were conducted with Modified Sawyer et al questionnaire that allowed for two-way communication and it was recorded for analysis.

\section{Plan for data analysis}

The interview is transcripted. The transcript will then be read once more, in order to divide the data into meaning units. The meaning units which are found to have a similar focus or content are integrated in order to clarify the sense of them. The phenomena is identified that is under study. The articulation is justified as of both the essential meanings and the general structure. Critical analysis of the work of the researcher is done.

Analysis is done by:

$>$ Descriptive statistics : Frequency and percentage distribution will be used to describe the demographic variables.

$>$ Inferential analysis: Chi-square will be used to associate the experiences of mothers with specific demographic data.

$>$ Thematic analysis
DATA ANALYSIS AND INTERPRETATION

Distribution of Demographic Variables Of Subjects.

Table 4.1: Distribution of Demographic VariablesAge.

\begin{tabular}{|l|l|l|}
\hline Age & No of subjects & Percentage (\%) \\
\hline $15-20$ & 4 & 20 \\
\hline $21-25$ & 7 & 35 \\
\hline $26-30$ & 8 & 40 \\
\hline $31-35$ & 1 & 5 \\
\hline
\end{tabular}

Table 4.1 and Figure 4.1 showed that, with regard to age, the majority $8(40 \%)$ of subjects were in the age of 26-30 years, (35\%) subjects were in the age group of 21-25 years and (20\%) subjects were in the age group of 15-20 years. Only 1 (5\%) of subjects were in the age group of 31-35 years.

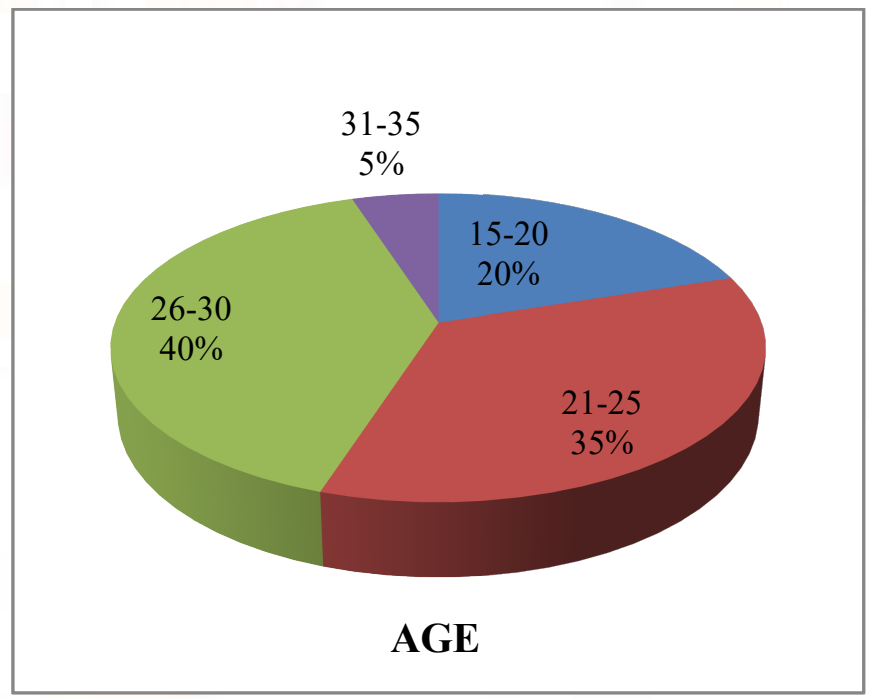

Figure 4.1: Distribution of Demographic Variables- Age. 
Table 4.2: Distribution Of Demographic VariablesDwelling Area.

\begin{tabular}{|l|l|l|}
\hline Dwelling area & $\begin{array}{l}\text { Number of } \\
\text { subjects }\end{array}$ & $\begin{array}{l}\text { Percentage } \\
(\%)\end{array}$ \\
\hline Urban & 12 & 60 \\
\hline Rural & 8 & 40 \\
\hline
\end{tabular}

Table 4.2 and Figure 4.2 showed that, with regard to dwelling area majority $12(60 \%)$ of subjects were dwelling in urban area and $8(40.0 \%)$ subjects were from rural area.

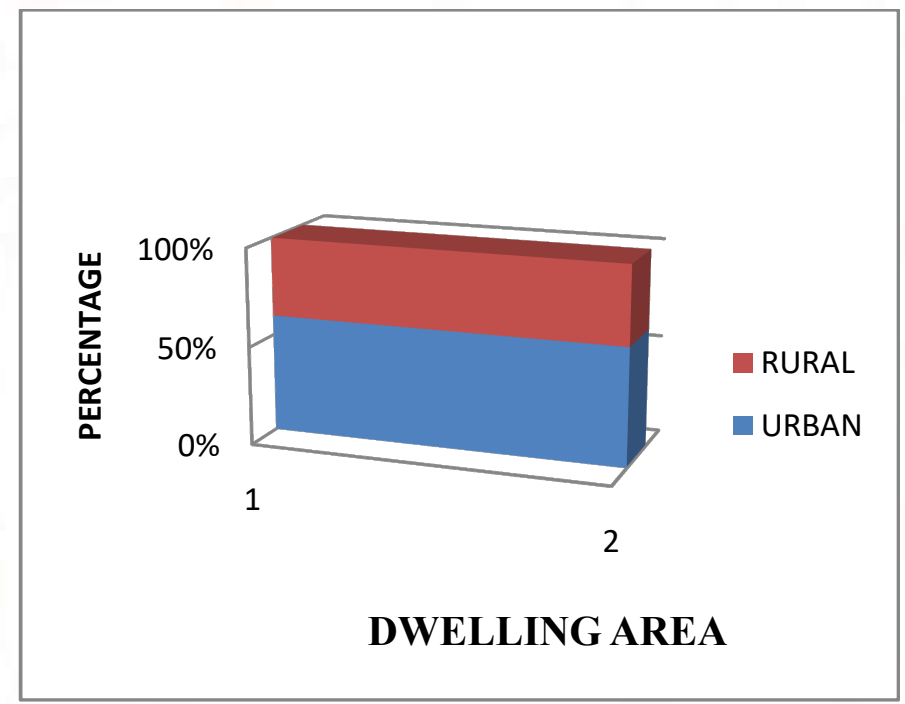

Figure 4.2: Distribution of Demographic Variables- Dwelling Area.

Table 4.3: Distribution Of Demographic VariablesEducation.

\begin{tabular}{|l|l|l|}
\hline \multicolumn{1}{|c|}{ Education } & \multicolumn{1}{|c|}{$\begin{array}{l}\text { Number of } \\
\text { subjects }\end{array}$} & \multicolumn{1}{|c|}{$\begin{array}{l}\text { Percentage } \\
\text { (\%) }\end{array}$} \\
\hline Post-graduate & 5 & 25 \\
\hline Graduate & 2 & 10 \\
\hline Diploma & 5 & 25 \\
\hline
\end{tabular}

\begin{tabular}{|l|l|l|}
\hline & & \\
High school & 4 & 20 \\
\hline & & \\
Middle school & 4 & 20 \\
\hline
\end{tabular}

Table 4.3 and Figure 4.3 showed that, with regard to educational qualification, majority $5(25 \%)$ of the subjects are post-graduates and diploma holders and 4 $(20 \%)$ of the subjects pursued high school and middle school education. Only $2(10.0 \%)$ of the subjects were graduates.

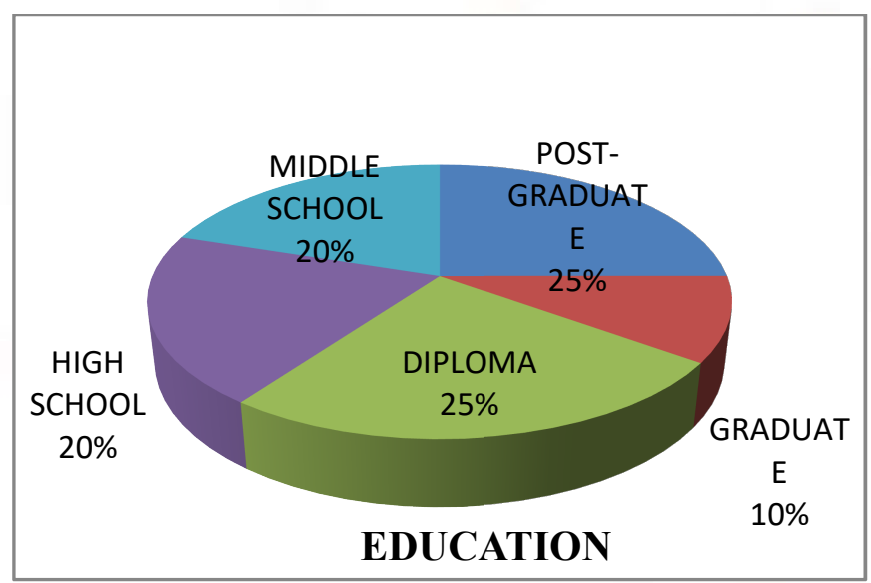

Figure 4.3: Distribution of Demographic Variables-Education

Table 4.4: Distribution of Demographic VariablesEmployment

\begin{tabular}{|c|c|c|}
\hline Employment & $\begin{array}{c}\text { No of } \\
\text { Subjects }\end{array}$ & $\begin{array}{c}\text { Percentage } \\
\mathbf{( \% )}\end{array}$ \\
\hline Semi-profession & 3 & 15 \\
\hline Clerical & 2 & 10 \\
\hline Unskilled worker & 1 & 5 \\
\hline Unemployed & 14 & 70 \\
\hline
\end{tabular}

Table 4.4 and Figure 4.4 showed that, regarding employment, majority $14(70 \%)$ of the subjects were unemployed and were homemakers, $3(15 \%)$ of the subjects belonged to semi-profession and $2(10 \%)$ of the subjects were doing clerical jobs. Only $(5 \%)$ of the subjects were unskilled worker. 


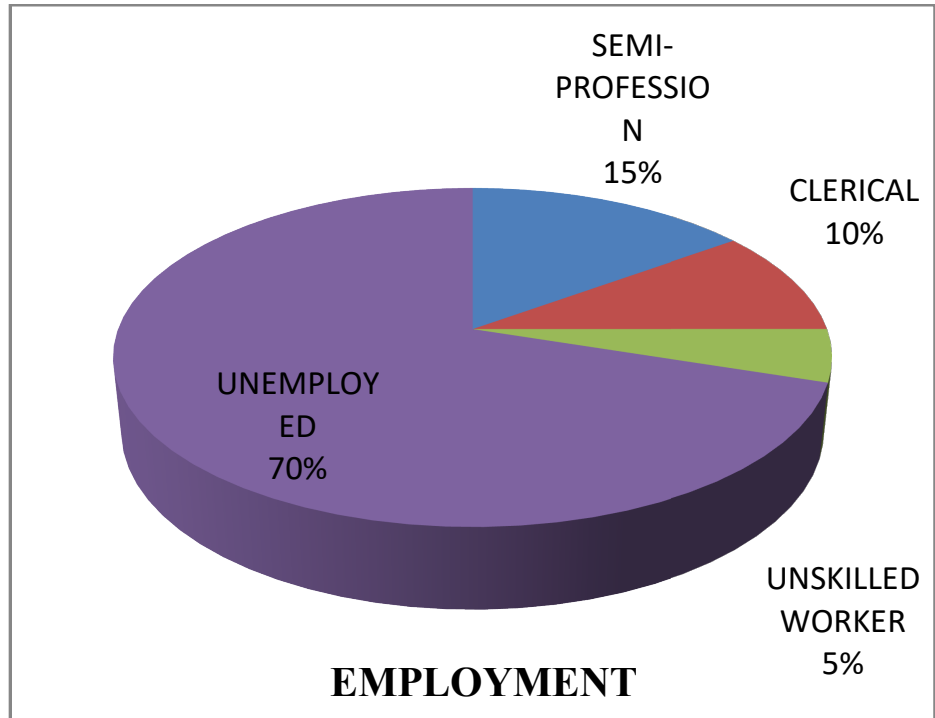

Figure 4.4: Distribution of Demographic Variables- Employment.

Table 4.5: Distribution of Demographic VariablesMonthly Income.

\begin{tabular}{|c|l|l|}
\hline $\begin{array}{c}\text { Income } \\
(\mathbf{r s})\end{array}$ & $\begin{array}{c}\text { Number of } \\
\text { subjects }\end{array}$ & $\begin{array}{c}\text { Percentage } \\
(\%)\end{array}$ \\
\hline $16020-32049$ & 5 & 25 \\
\hline $12021-16019$ & 2 & 10 \\
\hline $8010-12019$ & 3 & 15 \\
\hline $4810-8009$ & 2 & 10 \\
\hline $1601-4809$ & 6 & 30 \\
\hline$<=1600$ & 2 & 10 \\
\hline
\end{tabular}

Table 4.5 and Figure 4.5 showed that, with regard to income, majority $6(30 \%)$ of the subjects belonged to income of 1601-4809, 5 (25\%) of subjects belonged to income of $16020-32049$ and $3(15 \%)$ of the subjects belonged to income of 8010-12019. Only 2 $(10 \%)$ of the subjects belonged to income of 12021$16019,4810-8009$ and less than or equal to 1600 .

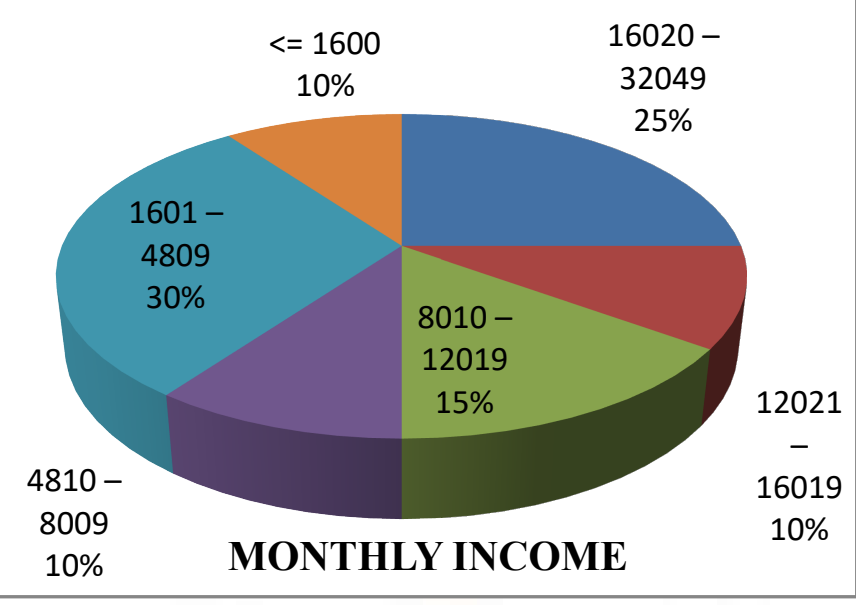

Figure 4.5: Distribution of Demographic Variables- Monthly Income.

Table 4.6: Distribution of Demographic VariablesSocio-Economic Class.

\begin{tabular}{|c|c|c|}
\hline $\begin{array}{c}\text { Socio- } \\
\text { economic class }\end{array}$ & $\begin{array}{c}\text { No of } \\
\text { subjects }\end{array}$ & $\begin{array}{c}\text { Percentage } \\
\text { (\%) }\end{array}$ \\
\hline Upper middle & 6 & 30 \\
\hline Lower middle & 5 & 25 \\
\hline Upper lower & 9 & 45 \\
\hline
\end{tabular}

Table 4.6 and Figure 4.6 showed that, with regard to socio-economic class, majority $9(45 \%)$ of the subjects belonged to upper-lower class, $6(30 \%)$ of the subjects belonged to upper-middle class and $5(25 \%)$ of the subjects belonged to lower-middle class.

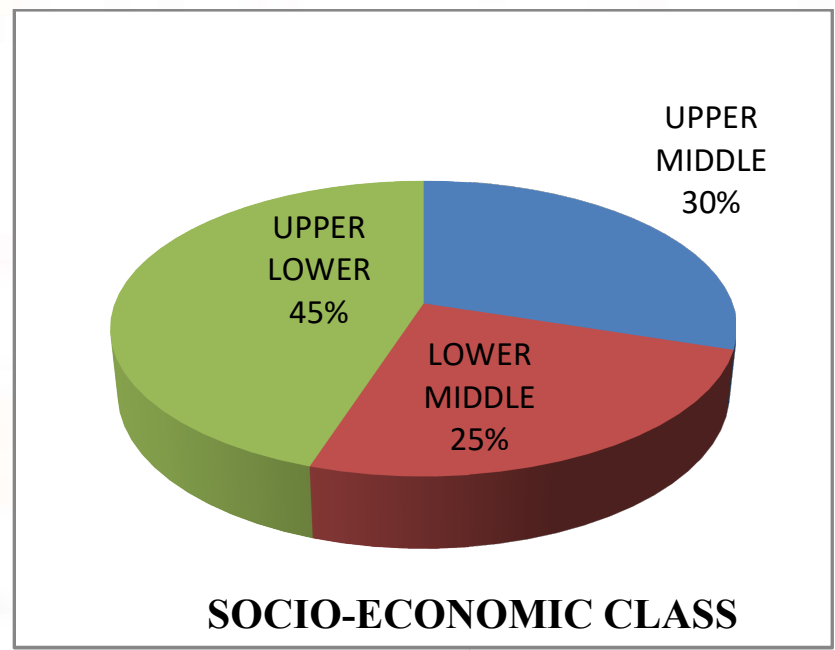

Figure 4.6: Distribution of Demographic Variables- Socio-Economic Class 
Table 4.7: Distribution of Demographic Variables-

High-Risk Conditions.

\begin{tabular}{|c|c|c|}
\hline $\begin{array}{c}\text { High-Risk } \\
\text { Conditions }\end{array}$ & $\begin{array}{c}\text { Number Of } \\
\text { Subjects }\end{array}$ & $\begin{array}{c}\text { Percentage } \\
(\mathbf{\%})\end{array}$ \\
\hline PIH & 11 & 55 \\
\hline Oligohydramnios & 2 & 10 \\
\hline Hypothyroidism & 4 & 20 \\
\hline Anemia & 2 & 10 \\
\hline Bronchial asthma & 2 & 10 \\
\hline Twin gestation & 2 & 10 \\
\hline Obesity & 1 & 5 \\
\hline Edema & 2 & 10 \\
\hline Eclampsia & 2 & 10 \\
\hline GDM & 3 & 15 \\
\hline
\end{tabular}

Table 4.7 and Figure 4.7 showed that, with regard to the high-risk condition, the majority 11 (55\%) subjects had PIH, 4 (20\%) subjects had hypothyroidism, 3 (15\%) subjects had GDM and 2 $(10 \%)$ subjects had oligohydramnios, anaemia, bronchial asthma, twin pregnancy, oedema and eclampsia each. Only $1(5 \%)$ of the subjects were obese.

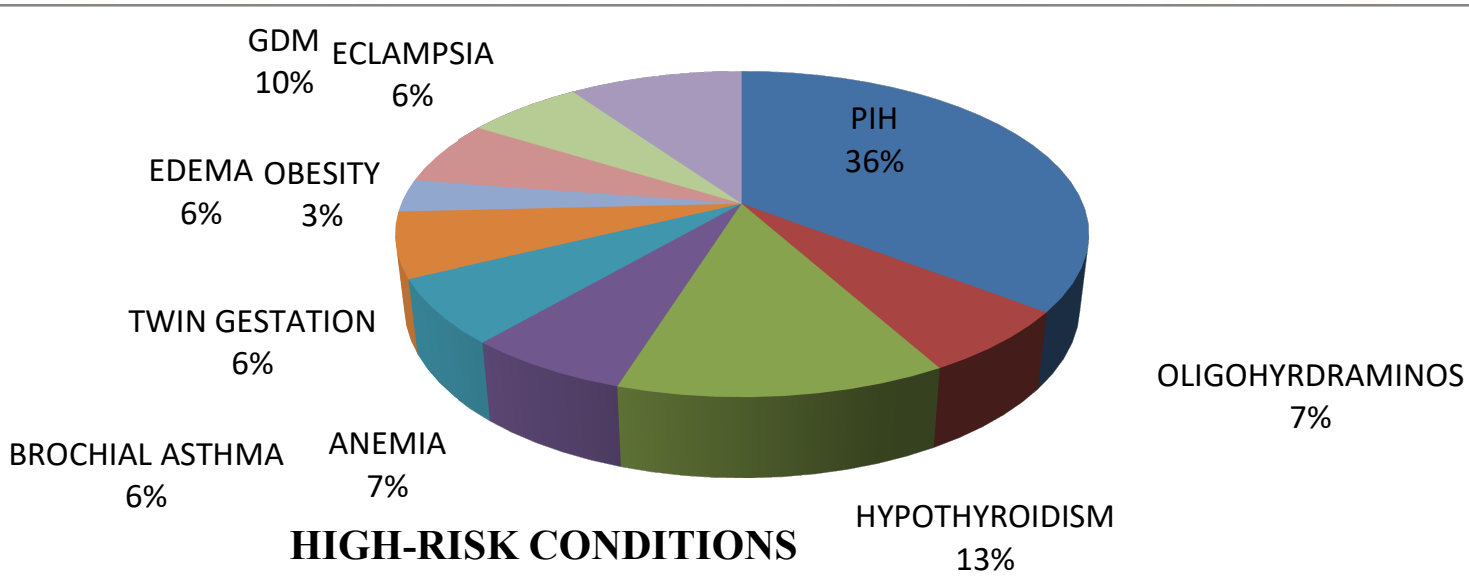

Figure 4.7: Distribution of Demographic Variables-High-Risk Conditions. 
SECTION - II

\section{Distribution of thematic analysis}

\section{THEME 1: FIRST DISCOVERY OF CONCEPTION}

Table 4.8: Frequency And Percentage Of First Discovery Of Conception.

\begin{tabular}{|c|c|c|}
\hline $\begin{array}{c}\text { First discovery } \\
\text { of conception } \\
\text { (days) }\end{array}$ & Frequency & Percentage (\%) \\
\hline $1-5$ & 5 & 25 \\
\hline $6-10$ & 5 & 25 \\
\hline $11-15$ & 4 & 20 \\
\hline $16-20$ & 6 & 30 \\
\hline
\end{tabular}

Table 4.8 and figure 4.8 showed the frequency when the mother discovered that she was pregnant. Majority $6(30 \%)$ of subjects reported that they had delayed periods of 16-20 days, 5 (25\%) subjects had delayed periods of 1-10 days and 4 (20\%) had delayed periods of 11-15 days.

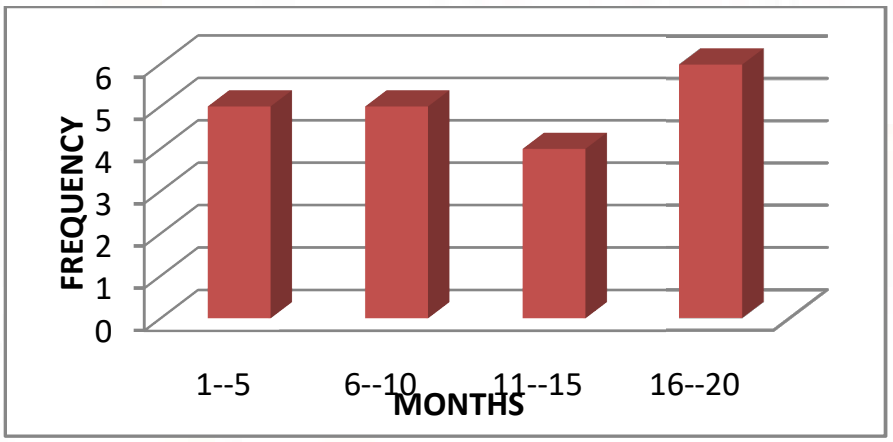

Figure 4.8: Frequency And Percentage Of First Discovery Of Conception.

\section{THEME 2: EXPERIENCES BEFORE CONCEPTION.}

The theme 2 was titled as "Experiences before conception." When the mothers were interviewed about their experiences before they found out that they were pregnant, the mothers narrated some of the common issues faced by them. Majority of the participants stated that they were questioned about the delay in pregnancy. Some of them narrated about their healthy way of living. Whereas on the other hand some mothers were already going to the health care centre for regular check-ups.

Table 4.9: Frequency And Percentage Of Experiences Before Conception.

\begin{tabular}{|c|c|c|}
\hline $\begin{array}{c}\text { Experiences } \\
\text { before } \\
\text { conception }\end{array}$ & Frequency & Percentage (\%) \\
\hline Normal life & 7 & 35 \\
\hline Healthy & 5 & 25 \\
\hline $\begin{array}{c}\text { Question for } \\
\text { delay }\end{array}$ & 3 & 15 \\
\hline $\begin{array}{c}\text { Previously } \\
\text { going to the } \\
\text { hospital }\end{array}$ & 5 & 25 \\
\hline
\end{tabular}

Table 4.9 and figures 4.9 showed the frequency of experiences of subjects before conception. Majority $35(7 \%)$ of subjects reported that they had normal life, $5(25 \%)$ of subjects reported that they were healthy and previously going to the hospital and $3(15 \%)$ reported that they were questioned about delay in conception.

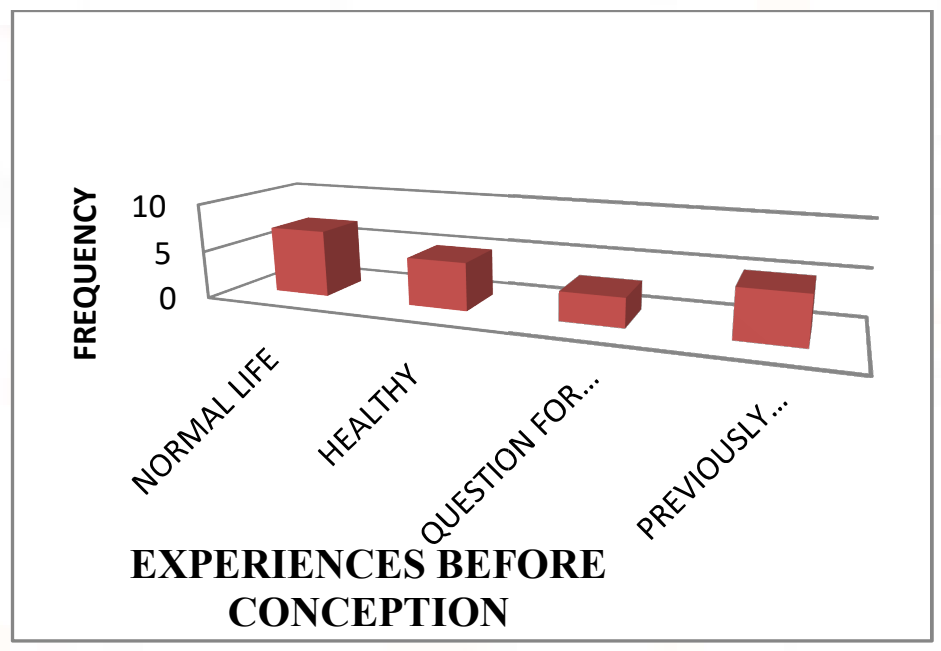

Figure 4.9: Frequency And Percentage Of Experiences Before Conception.

\section{THEME 3: BIG CHANGE IN LIFE}

The theme 3 was titled as "Big change in life." When the researched interviewed about the changes in the mothers' life after conception, they stated that it was a big change in their life. Majority of the mothers experienced excitement. Some of the participants 
decided to become mature after conception. Many experienced some discomforts. However, some experienced a high degree of completeness.

Table 4.10: Frequency And Percentage Of Big Change In Life.

\begin{tabular}{|c|c|c|}
\hline $\begin{array}{c}\text { Big change in } \\
\text { life }\end{array}$ & Frequency & Percentage (\%) \\
\hline Happiness & 8 & 40 \\
\hline Commitment & 1 & 5 \\
\hline Maturity & 2 & 10 \\
\hline Completeness & 3 & 15 \\
\hline Extra care & 3 & 15 \\
\hline Discomforts & 3 & 15 \\
\hline
\end{tabular}

Table 4.10 and figures 4.10 showed the frequency of the categories for the theme "big change in life." Majority $8(40 \%)$ of the subjects reported happiness, 3 (15\%) reported completeness, extra care and discomforts, $2(10 \%)$ reported maturity and only 1 (5\%) reported commitment.

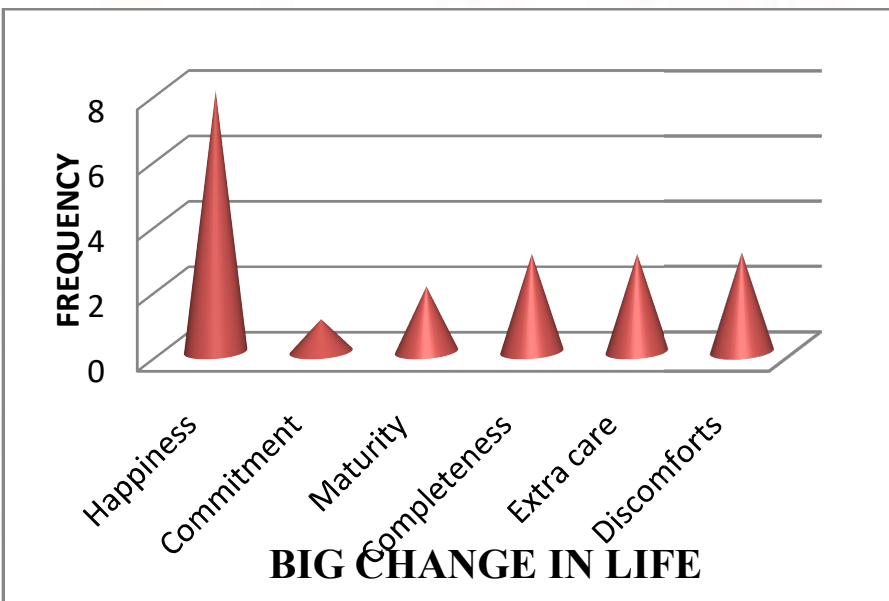

Figure 4.10: Frequency and percentage of big change in life.

\section{THEME 4: LIFE AFTER DIAGNOSIS}

The theme 4 was labelled as "Life after diagnosis." When the researcher interviewed the subjects regarding how they felt after they were diagnosed with their condition, they narrated many factors. Most of the subjects experienced fear and worry about the pregnancy outcome. Whereas, others narrated that they took extra precautions after they were diagnosed with a specific condition.

Table 4.11: Frequency And Percentage Of Life After Diagnosis.

\begin{tabular}{|c|c|c|}
\hline $\begin{array}{l}\text { Life after } \\
\text { diagnosis }\end{array}$ & Frequency & Percentage (\%) \\
\hline Lost confidence & 1 & 5 \\
\hline Increase fear & 4 & 20 \\
\hline $\begin{array}{c}\text { Frequent } \\
\text { hospital visits }\end{array}$ & 3 & 15 \\
\hline $\begin{array}{c}\text { Extra } \\
\text { precautions }\end{array}$ & 5 & 25 \\
\hline $\begin{array}{c}\text { Struggling to } \\
\text { believe }\end{array}$ & 3 & 15 \\
\hline $\begin{array}{c}\text { Worried about } \\
\text { outcome }\end{array}$ & 4 & 20 \\
\hline
\end{tabular}

Table 4.11 and figure 4.11 showed the frequency of categories under the theme "Life after diagnosis." Majority $5(25 \%)$ of subjects reported that they took extra precautions, $4(20 \%)$ of subjects reported increased fear and worried about outcome and 3 $(15 \%)$ had frequent hospital visits and were struggling to believe.

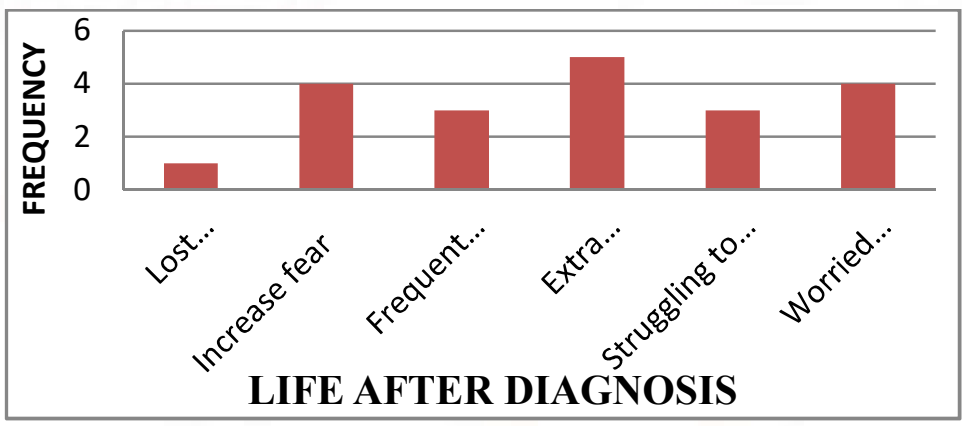

Figure 4.11: Frequency And Percentage Of Life After Diagnosis.

\section{THEME 5: NEARING DUE}

Theme 5 is entitled as "Nearing due." When the researcher interviewed the subjects regarding their experiences, they narrated many factors. Many of the 
subjects experienced fear, while others felt it exciting to deliver soon. Some of the subjects narrated that they were shocked because they had their delivery well in advance than their expected delivery date. A few subjects were worried if they will go in for caesarean section.

Table 4.12: Frequency And Percentage Of Nearing Due.

\begin{tabular}{|c|c|c|}
\hline Nearing due & Frequency & Percentage (\%) \\
\hline Fear & 4 & 20 \\
\hline Excited & 3 & 15 \\
\hline Positivity & 2 & 10 \\
\hline Happy & 3 & 15 \\
\hline Anxious & 1 & 5 \\
\hline Worried & 7 & 35 \\
\hline
\end{tabular}

Table 4.12 and figures 4.12 showed the frequency of categories under the theme "Nearing due". Majority 7 (35\%) were worried, $4(20 \%)$ were afraid, $3(15 \%)$ were excited and happy, $2(10 \%)$ were positive and 1 $(5 \%)$ were anxious.

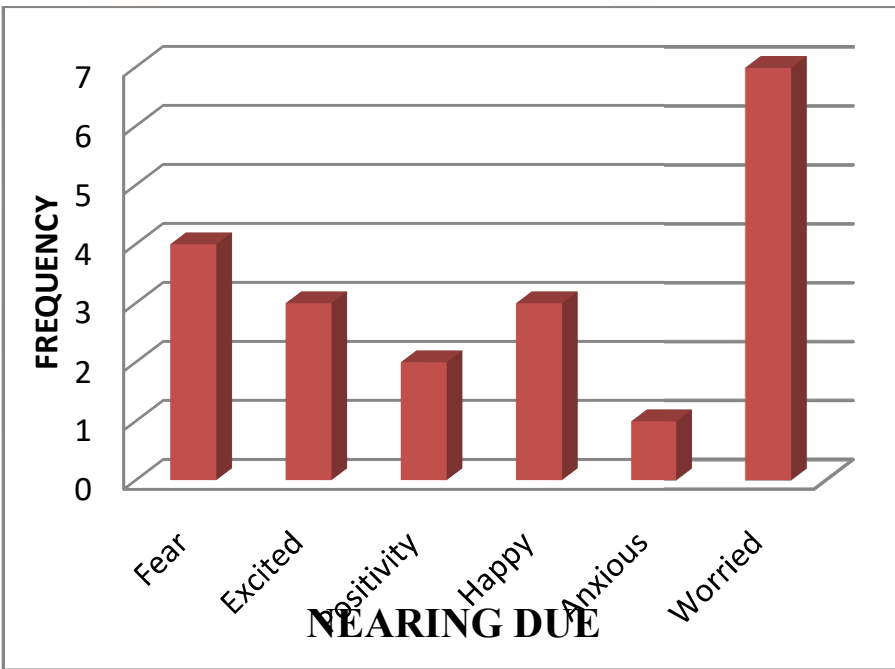

Figure 4.12: Frequency And Percentage Of Nearing Due.

THEME 6: EXPECTATIONS OF PREGNANCY OUTCOME

The theme 6 was labelled as "Expectations of pregnancy outcome." The researcher interviewed the subjects regarding their preferences of their pregnancy outcome. Many of the subjects opted for female child rather than male child. Whereas, few subjects did not expect for any child, they just wanted their child to be born healthy and safe. It was been noted that many of the males wanted female children.

Table 4.13: Frequency And Percentage Of Expectations Of Pregnancy Outcome

\begin{tabular}{|c|c|c|}
\hline $\begin{array}{c}\text { Expectations of } \\
\text { pregnancy } \\
\text { outcome }\end{array}$ & Frequency & Percentage (\%) \\
\hline Male & 7 & 35 \\
\hline Female & 10 & 50 \\
\hline No expectation & 3 & 15 \\
\hline
\end{tabular}

Table 4.13 and figure 4.13 showed the frequency of the expectations of pregnancy outcome. Majority 10 $(50 \%)$ wanted female child, 7 (35\%) wanted male child and $3(15 \%)$ did not have any expectations.

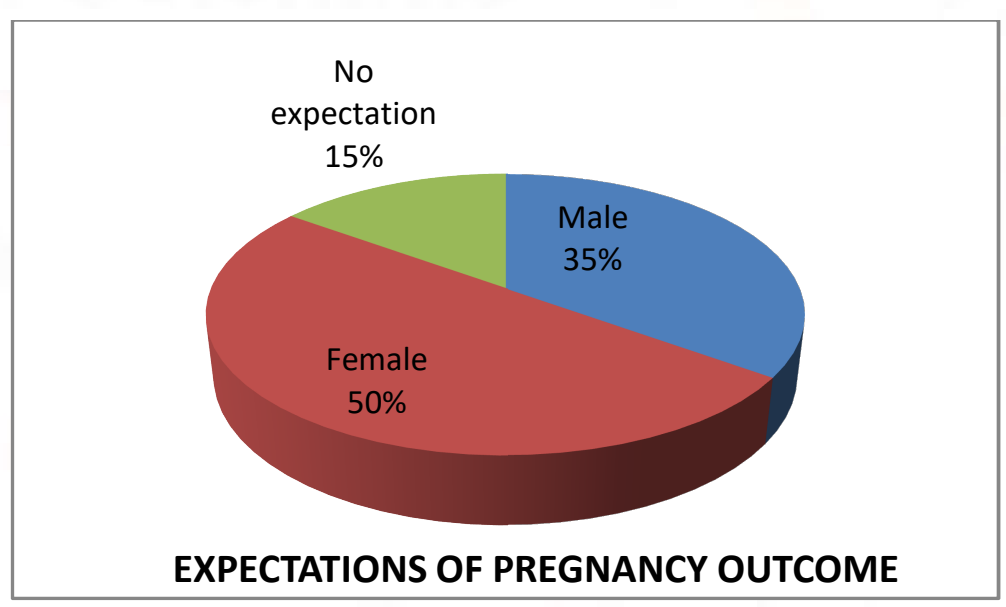

Figure 4.13: Frequency And Percentage Of Expectations Of Pregnancy Outcome

\section{THEME 7: BIRTH TAKEN ONCE AGAIN}

Theme 7 was titled as "Birth taken once again." The researcher interviewed the subjects regarding their experiences during the time of delivery. Many of the subjects reported that they do not want to go in for a second child, whereas, some wanted caesarean 
section. Few narrated that they could tolerate the pain and it was not as much as they expected. Couple of subjects narrated that they thought about their mothers how they tolerated the pain and delivered.

Table 4.14: Frequency And Percentage Of Birth Taken Once Again.

\begin{tabular}{|l|c|c|}
\hline \multicolumn{1}{|c|}{$\begin{array}{c}\text { Birth taken } \\
\text { once again }\end{array}$} & Frequency & Percentage (\%) \\
\hline $\begin{array}{l}\text { Thought about } \\
\text { mother }\end{array}$ & 2 & 10 \\
\hline $\begin{array}{l}\text { No need of } \\
\text { second }\end{array}$ & 5 & 25 \\
\hline Trust in God & 2 & 10 \\
\hline $\begin{array}{l}\text { Opting for } \\
\text { surgery }\end{array}$ & 4 & 20 \\
\hline Hopelessness & 2 & 10 \\
\hline Embarrassment & 1 & 5 \\
\hline Tolerable pain & 4 & 20 \\
\hline
\end{tabular}

Table 4.14 and figure 4.14 showed the frequency of categories under the theme "Birth taken once again." Majority $5(25 \%)$ narrated that they did not want a second child, $4(20 \%)$ opted for surgery. $2(10 \%)$ were hopeless and $1(5 \%)$ were embarrassed.

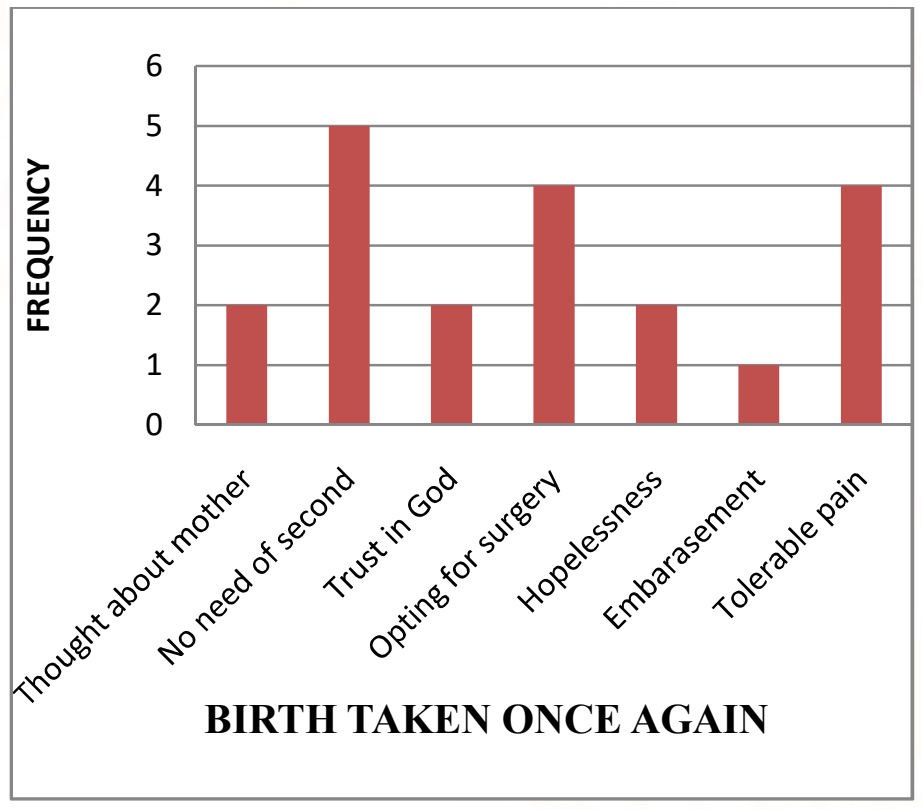

Figure 4.14: Frequency And Percentage Of Birth Taken Once Again.

\section{THEME 8: NEED FOR SUPPORT}

The theme 8 was titled as "Need for support." The researcher interviewed the subjects and found out that many of the mothers needed support either from their family members or from staffs during their delivery. Majority of the subjects wanted support from their mothers. They wanted them to stay with them during delivery. Few wanted their husbands to be with them.

Table 4.15: Frequency And Percentage Of Need For Support.

\begin{tabular}{|c|c|c|}
\hline Need for support & Frequency & Percentage (\%) \\
\hline Husband & 4 & 20 \\
\hline Mother & 6 & 30 \\
\hline $\begin{array}{c}\text { Both Mother and } \\
\text { husband }\end{array}$ & 2 & 10 \\
\hline Staffs & 3 & 15 \\
\hline No support needed & 5 & 25 \\
\hline
\end{tabular}

Table 4.15 and figures 4.15 showed the frequency of categories under the theme "need for support." Majority $6(30 \%)$ wanted their mother, 5 (25\%) did not want support, $4(20 \%)$ wanted their husband and 2 $(10 \%)$ wanted both their mother and husband.

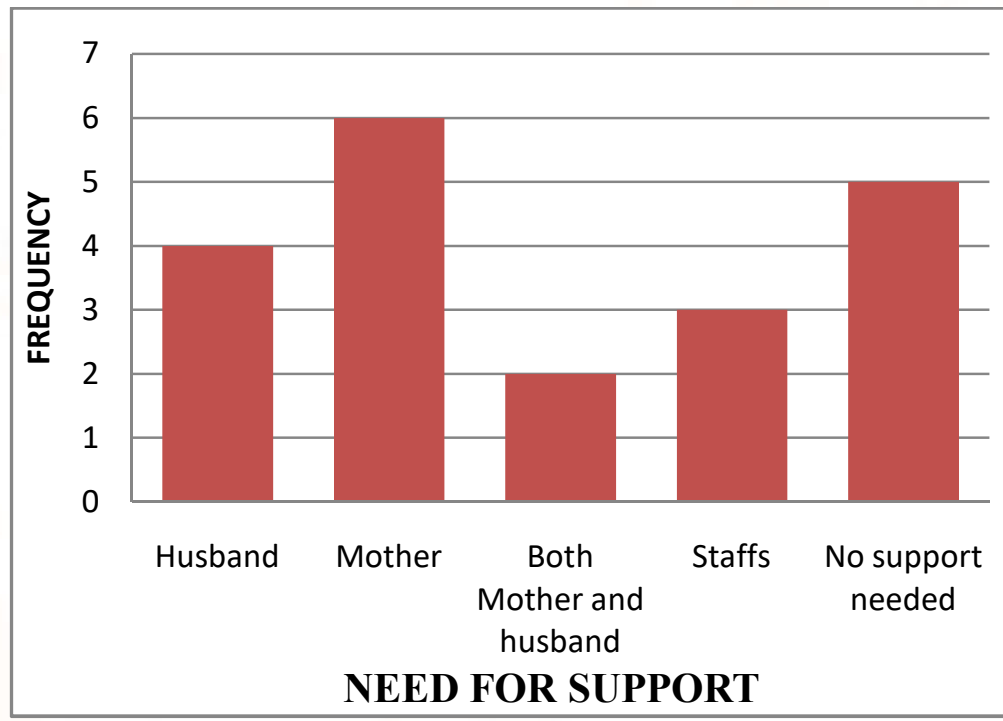

Figure 4.15: Frequency And Percentage Of Need For Support. 


\section{THEME 9: FIRST SENSITIVE HOURS OF MOTHERHOOD}

Theme 9 titled as "First sensitive hours of motherhood." The researcher interviewed the subjects regarding how they felt about being a new mother. Most of the subjects narrated that they were happy about being a mother, whereas others were relieved after they have delivered. A few subjects complained that they were disappointed and were shocked seeing their baby.

Table 4.16: Frequency And Percentage Of First Sensitive Hours Of Motherhood.

\begin{tabular}{|l|c|c|}
\hline $\begin{array}{c}\text { First sensitive hours } \\
\text { of motherhood }\end{array}$ & Frequency & $\begin{array}{c}\text { Percentage } \\
(\%)\end{array}$ \\
\hline Relief & 6 & 30 \\
\hline Happiness & 7 & 35 \\
\hline Completeness & 4 & 20 \\
\hline Disappointment & 1 & 5 \\
\hline Shock & 1 & 5 \\
\hline Reward & 1 & 5 \\
\hline
\end{tabular}

Table 4.16 and figures 4.16 showed the frequency of categories under the theme "first sensitive hours of motherhood." Majority 7 (35\%) of mothers reported happiness, $6(30 \%)$ reported relief, $4(20 \%)$ reported completeness and 1 reported (5\%) disappointment, shock and reward.

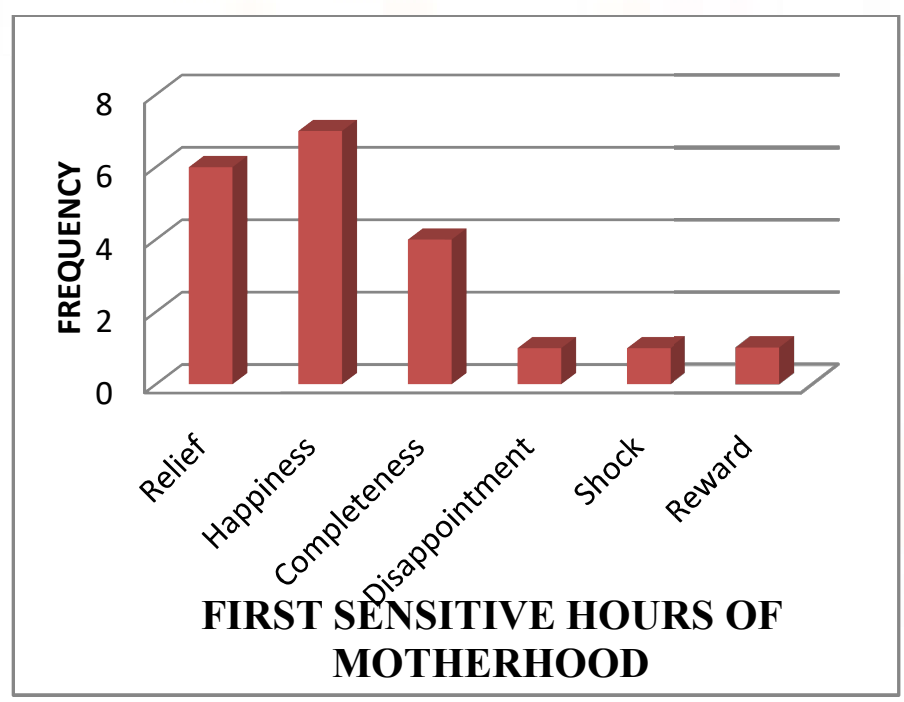

Figure 4.16: Frequency And Percentage Of First Sensitive Hours Of Motherhood
THEME 10: LIVING IN A NEW AND OVERWHELMING WORLD

Theme 10 titled as "Living in a new and overwhelming world." The researcher interviewed the subjects regarding their experiences in their postnatal period. Many of the subjects reported that they had poor knowledge regarding baby care and they had increased responsibility to take care of their baby. Some subjects reported that it is a new experience, while others narrated that they have mild financial burden after their delivery.

Table 4.17: Frequency And Percentage Of Living In A New And Overwhelming World

\begin{tabular}{|l|c|c|}
\hline $\begin{array}{l}\text { Living in a new and } \\
\text { overwhelming world }\end{array}$ & Frequency & $\begin{array}{l}\text { Percentage } \\
(\mathbf{\% )}\end{array}$ \\
\hline $\begin{array}{l}\text { Poor knowledge } \\
\text { regarding baby care }\end{array}$ & 6 & 30 \\
\hline Financial burden & 5 & 25 \\
\hline Responsibility & 6 & 30 \\
\hline New experience & 3 & 15 \\
\hline
\end{tabular}

Table 4.17 and figures 4.17 showed the frequency of categories under the theme "Living in a new and overwhelming world." Majority $6(30 \%)$ had poor knowledge regarding baby care and responsibility, 5 $(25 \%)$ had financial burden and $3(15 \%)$ had a new experience.

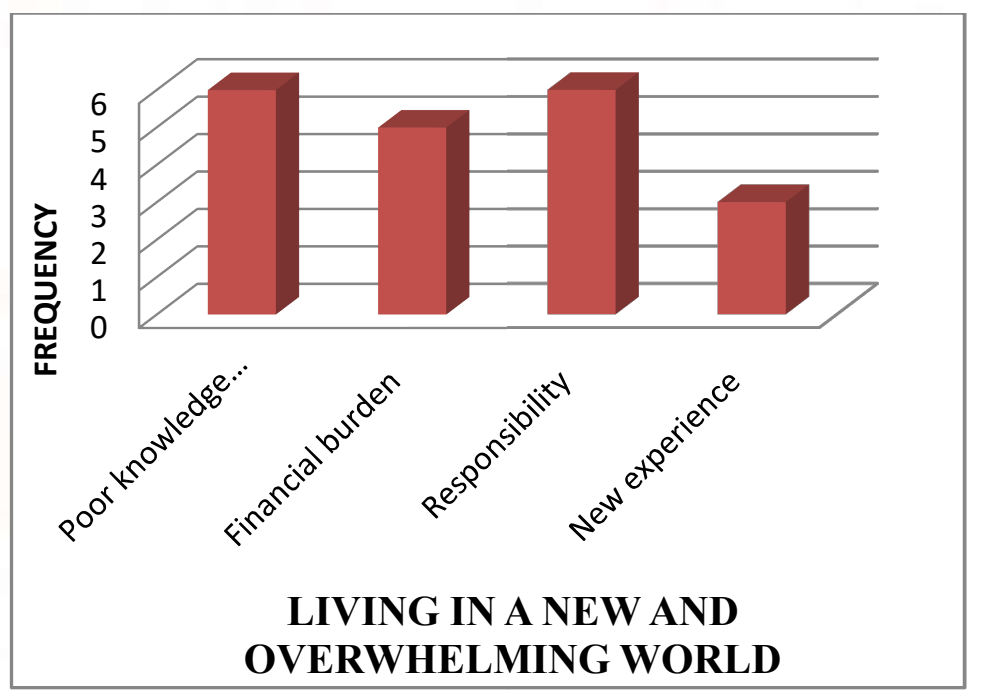

Figure 4.17: Frequency And Percentage Of Living In A New And Overwhelming World 


\section{DISCUSSION}

The study was conducted to explore the experiences of high-risk mothers who were admitted in RGGW\&CH, Pondicherry. This chapter begins with discussion of the present study that was based on the codes and themes obtained from the thematic analysis of transcribed verbatim.

First objective of the study is to explore the women's experiences on pregnancy. The result highlighted that majority $25 \%$ of the participants took extra precautions, $20 \%$ of the participants had increased fear and were worried about their outcome and $15 \%$ were struggling to believe that they had the disease.

The second objective of the study is to explore the women's experiences on- childbirth. Theme 7 and 8 focused and described this objective. The findings showed that majority of the participants $25 \%$ did not want another child, $20 \%$ opted for surgery and $10 \%$ thought about their mother, lost hope. Majority of the participants 30\% wanted support from their mother and $20 \%$ wanted support from their husband.

Third objective of the study is to explore the women's experiences on postnatal period. Themes 9 and 10 focused and explained this objective. The findings showed that majority of the participants $30 \%$ had poor knowledge regarding baby care and had increased responsibility. $30 \%$ had financial burden and $15 \%$ had a new experience. $30 \%$ of the participants were relieved whereas $20 \%$ had a feel of completeness.

The fourth objective of the study is to associate the experiences of high-risk mothers with specific demographic data. After inferential analysis the researcher found that there was no association between the experiences and the demographic data.

\section{Major findings of the study:}

The major findings from this study were 30\% discovered that they were pregnant within 16-20 days, $25 \%$ took extra precautions after the diagnosis of the disease, $35 \%$ were worried when they were nearing due, 50\% expected girl child, 30\% wanted their mother's support during delivery, 25\% had some financial burden and $30 \%$ had increased responsibility.

\section{IMPLICATIONS OF THE STUDY}

- Multi- dimensionally viewing the experiences, belief, values and expectation of mothers, brought to light their life.

- Diagnosis of the disease condition and scary life after knowing about their condition, treatment experiences and the outcome of pregnancy are new experiences for the mothers. Therefore, by understanding their views, psychological preparations and supportive measures to overcome the situation and adopt the remedies are required for the high-risk mothers.

- Nursing administrator should plan the discussion section weekly for the nurses to organize and discuss the high-risk disease condition which is leading and prone to get the higher incidence and also encourage to do paper presentation regarding treatment regimens, care and support.

\section{RECOMMENDATIONS}

- The same study can be conducted by using other quantitative research methods.

- Hospitals from which sample was drawn in the present study was located in a suburban area in a small-sized Union territory. The study can be replicated in both urban and rural hospitals and specialty centers. Since the reality of location involved only Tamil people influenced by South Indian culture, further studies should include ample number of individuals from other nations- assessing to what degree multicultural variables affect the present findings. 
- In this study, samples chosen were high-risk mother who are delivered at Puducherry. Heterogeneous sample can be chosen.

- This study can also be used to explore the experiences of husbands of high-risk mothers.

In this study all high-risk mothers' experienced were explored. Exploration of high-risk mothers with specific conditions can also be studied. 